\title{
Good facility of use is obtained with the interactive application 'Preventing' that creates long-lasting patient support: A novel approach to improve treatment adherence in the post-transplant period
}

\author{
Authors: Jorge Morales-Barria, ${ }^{A}$ Pedro Johansson, ${ }^{A}$ Felipe Morales ${ }^{B}$ and Maria Elena Lueje
}

\begin{abstract}
Aims
Non-adherence to immunosuppressive drug intake is a frequent condition affecting renal transplant recipients, leading to premature transplanted organ loss. Measures adopted to prevent and correct non-adherence are not fully effective because they need to increase the personnel dedicated to patients' support, or because the methods are expensive and difficult to implement in the long run. A new model of medical application, characterised by an active participation of the users is presented here ( $w w w$. preventingapp.com)
\end{abstract}

\section{Methods}

The active patient's role related to the app consisted in filling compliance and medical surveys, following-up the evolution of parameters (graphics appearing in dashboard are shown in Fig 1), easy contact with transplant staff, reminders etc. The clinical information is collected in the transplant center's back office, allowing the staff to be informed of patient evolution especially barriers to adherence. 'Preventing' app is installed in Apple and Google stores in English, Spanish and Portuguese. Only patients authorised by a transplant centre can access the app and own data with a password. Six stable kidney transplant recipients, after giving informed consent, were enrolled to study app usability in an 11-month period; all used iOS mobile phones. Patients' digital skills previous to the study were evaluated according to the GSMA Digital Literacy Journey that differentiates four stages (Table 1). To quantify patients' app 'Preventing' usability, data obtained of compliance and medical surveys fulfilled during the study were used, calculating the mean of six items (scale 0 to 5) (Table 2).

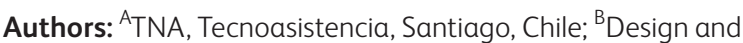
Innovation, Fyord, Stockholm, Sweden; ' Inversiones Rio Baker S.A., Santiago, Chile

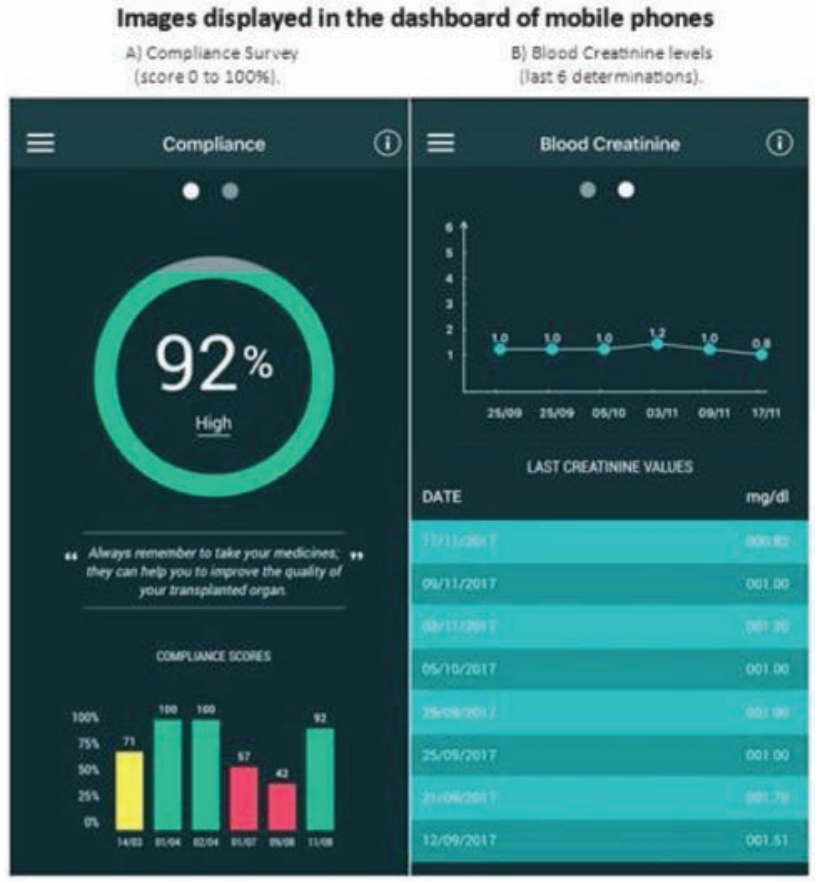

Fig 1. Image of the graphics appearing on the app dashboard.

Results

The skills previous to the study showed that only a half of patients were prepared to use the app correctly. As would be expected those patients with good digital skills also demonstrated good scores in the 'measured usability'. All patients described the experience as useful and enjoyable (data not shown).

\section{Conclusion}

This first preliminary experience with the app 'Preventing' showed that patients used it pleasantly and with an acceptable usability score when previous digital skills were appropriate. A study with 


\begin{tabular}{|c|c|c|c|c|c|c|c|}
\hline Patient & $\begin{array}{l}\text { Age at } \\
\text { the study }\end{array}$ & Gender & $\begin{array}{l}\text { Profession / } \\
\text { activity }\end{array}$ & $\begin{array}{l}\text { Transplant } \\
\text { duration (years) }\end{array}$ & $\begin{array}{l}\text { Last creatinine } \\
\text { level }(\mathrm{mg} / \mathrm{dL})\end{array}$ & $\begin{array}{l}\text { Previous to the study } \\
\text { grade of digital skills* }\end{array}$ & $\begin{array}{l}\text { Observation } \\
\text { period (months) }\end{array}$ \\
\hline 1 & 67 & M & Businessman & 17 & 0.8 & 1 & 11 \\
\hline 2 & 75 & $\mathrm{~F}$ & Artist & 18 & 0.9 & 2 & $5^{* *}$ \\
\hline 3 & 27 & M & Student & 9 & 1.2 & 4 & 10 \\
\hline 4 & 40 & M & Employee & 15 & 1.6 & 4 & 11 \\
\hline 5 & 54 & M & Engineer & 4 & 1.3 & 4 & 10 \\
\hline 6 & 43 & M & Employee & 21 & 1.3 & 3 & 11 \\
\hline
\end{tabular}

\begin{tabular}{|c|c|c|c|c|c|c|c|}
\hline Patient & $\begin{array}{l}\text { Confirm } \\
\text { medicine } \\
\text { intake }\end{array}$ & $\begin{array}{l}\text { Take } \\
\text { medicine } \\
\text { on time }\end{array}$ & $\begin{array}{l}\text { Fill surveys asking } \\
\text { for creatinine } \\
\text { levels }\end{array}$ & $\begin{array}{l}\text { Fill out } \\
\text { medical } \\
\text { survey }\end{array}$ & $\begin{array}{l}\text { Fill out } \\
\text { compliance } \\
\text { survey }\end{array}$ & $\begin{array}{l}\text { Medical } \\
\text { and nurse } \\
\text { appointments }\end{array}$ & $\begin{array}{l}\text { Mean measured } \\
\text { usability ( } 0 \text { to } 5)\end{array}$ \\
\hline 1 & 0 & 0 & 0 & 0 & 0 & 0 & 0 \\
\hline 2 & 5 & 5 & 5 & 0 & 1 & 0 & 2.7 \\
\hline 3 & 5 & 5 & 4 & 4 & 4 & 5 & 4.5 \\
\hline 4 & 4 & 4 & 4 & 4 & 4 & 0 & 3.3 \\
\hline 5 & 5 & 5 & 5 & 5 & 5 & 5 & 5 \\
\hline 6 & 0 & 0 & 1 & 1 & 1 & 1 & 0.7 \\
\hline
\end{tabular}

a greater number of patients is needed to establish if the app improves adherence to treatment in the setting of transplanted recipients.

\section{Conflict of interest statement}

Authors declare not having conflict of interest. 